\title{
PENGARUH KOMPOSISI CAMPURAN LIMBAH PADAT DAN CAIR INDUSTRI TAPIOKA TERHADAP PERSENTASE PENYISIHAN TOTAL SUSPENDED SOLID (TSS) DENGAN STARTER KOTORAN SAPI
}

\author{
Syervy Tanata, Mimi Richell Gunawan, Setiaty Pandia \\ Departemen Teknik Kimia, Fakultas Teknik, Universitas Sumatera Utara, \\ Jl. Almamater Kampus USU Medan 20155, Indonesia \\ Email: syervy.tanata@students.usu.ac.id
}

\begin{abstract}
Abstrak
Limbah industri tapioka merupakan limbah organik yang masih banyak mengandung senyawasenyawa penting seperti karbohidrat, protein dan senyawa gula lainnya. Penelitian ini bertujuan untuk mengetahui kualitas gas bio yang dihasilkan dari ampas singkong yang dikombinasikan dengan limbah cair singkong dari industri tapioka dengan menggunakan digester anaerobik sistem batch . Penelitian diawali dengan mencampurkan limbah padat dan cair dengan perbandingan 70:30; 60:40; 50:50; 40:60; dan 30:70 (w/w) dengan starter kotoran sapi di dalam digester anaerobik sistem batch. Parameter uji yang dilakukan adalah terhadap persentase penyisihan Total Suspended Solid (TSS). Dari hasil penelitian yang telah dilakukan, diperoleh persentase penyisihan Total Suspended Solid (TSS) optimum adalah sebesar 76,2289\% pada perbandingan berat limbah padat dan cair sebesar 70:30 (w/w).
\end{abstract}

Kata kunci: limbah industri tapioka, digester anaerobik, TSS

\begin{abstract}
The waste from tapioca industry is classified as an organic waste that contains many important compounds such as carbohydrate, protein and glucose. The research is aimed to know the quality of biogas from cassava pulp combined with wastewater from the cassava starch industry using batch anaerobic digester system. The research began by mixing the solid and liquid wastes from tapioca industry at ratio 70:30; 60:40; 50:50; 40:60; and 30:70 (w/w) with starter from solid waste of cattle in a batch anaerobic digester. From this research, the optimum percentage reduction of Total Suspended Solid (TSS) was 76,2289\% at ratio of solid and liquid waste was 70:30 (w/w).
\end{abstract}

Key words: tapioka industry waste, anaerobic digester, TSS

\section{Pendahuluan}

Produksi energi yang berasal dari bahan bakar fosil menjadi semakin bermasalah setelah sumber daya ini semakin sedikit dan hasil pembakaran menyebabkan efek rumah kaca [7]. Hal ini menyebabkan munculnya beberapa pilihan, salah satunya adalah penggunaan gas yang dapat diperbaharui sebagai bahan bakar yaitu gas bio [6]. Bahan baku pembuatan gas bio dapat berasal dari limbah. Salah satunya adalah limbah industri tapioka dimana limbah ini memiliki kontribusi terhadap emisi gas metana [9]. Limbah tersebut baik cair maupun padat termasuk limbah organik yang masih banyak mengandung karbohidrat, protein dan gula. Selain itu, limbah padat juga masih banyak mengandung senyawa-senyawa gula seperti sukrosa, glukosa, fruktosa, dekstran, galaktosa dan asam nitrat sehingga dapat dijadikan sebagai bahan baku pembuatan gas bio [17]. Perumusan masalah dalam penelitian ini adalah mengetahui sejauh mana ampas singkong (Manihot utilissima) bila dikombinasikan dengan limbah cair singkong industri tapioka akan menghasilkan gas bio dengan menggunakan digester anaerobik sistem batch. Tujuan dari penelitian ini adalah mengetahui kualitas gas bio yang dihasilkan dari ampas singkong yang dikombinasikan dengan limbah cair singkong dari industri tapioka dengan menggunakan digester anaerobik sistem batch.

\section{Teori}

Singkong disebut ketela pohon atau ubi kayu. Singkong merupakan bahan baku berbagai produk industri, seperti industri makanan, farmasi, tekstil dan lain-lain. Industri pengolahan singkong dapat digolongkan menjadi tiga, yaitu hasil fermentasi singkong (tape), singkong yang dikeringkan (gaplek) dan tepung singkong atau tepung tapioka [17].

Pada industri pembuatan tapioka akan dihasilkan limbah cair dan padat. Limbah industri tapioka mengandung mineral-mineral (nitrogen, karbon, fosfor, kalium, kalsium, magnesium, sulfur, besi, mangan, tembaga dan natrium) [13], sehingga tidak bisa dibuang langsung ke lingkungan. Selain itu, limbah cair mengandung karbohidrat yang besar sehingga dapat diolah menjadi produk hasil fermentasi [16] dan dapat pula menjadi gas bio [11]. Begitu pula dengan 
limbah padat yang termasuk limbah organik yang masih banyak mengandung karbohidrat, protein dan gula. Selain itu juga masih banyak mengandung senyawa-senyawa gula seperti sukrosa, glukosa, fruktosa, dekstran, galaktosa dan asam nitrat [17].

Gas bio adalah gas yang dihasilkan oleh makhluk hidup, yaitu organisme berupa bakteri. Bakteri melakukan aktivitas penguraian bahanbahan organik dalam kondisi anaerob kemudian menghasilkan suatu gas. Proses penguraian bahan organik secara anaerob ini disebut sebagai pencernaan anaerob (anaerob digestion) dan peralatan yang memfasilitasi prosesnya disebut sebagai digester [12].

Pencernaan anaerobik adalah proses yang banyak digunakan diunit pengolahan limbah air kota. Pengurangan massa, produksi metana dan peningkatan mutu air atau sludge yang diolah adalah tujuan utama dari proses ini. Proses penguraian yang lama merupakan kelemahan dari sistem anaerobik. Proses pencernaan anaerobik ini dapat dilakukan pada kondisi psikrofilik, mesofilik dan termofilik. Secara umum, kondisi mesofilik paling banyak digunakan dibandingkan termofilik karena lebih sedikit energi yang dibutuhkan dan stabilitas proses yang tinggi [3]. Selain itu, ada beberapa faktor yang perlu diperhatikan dalam proses pembentukan gas bio, yaitu rasio $\mathrm{C} / \mathrm{N}$, kadar air, derajat keasaman $(\mathrm{pH})$, temperatur proses, lama fermentasi, keterlibatan mikroorganisme dan pengadukan [4].

\section{Metodologi Penelitian Bahan dan Alat}

Bahan yang digunakan adalah limbah padat dan cair industri tapioka sebagai bahan baku, sebagai bahan pembantu digunakan molase dan mikroorganisme yang berasal dari kotoran sapi yang dicampur dengan air dengan perbandingan 1:1 yaitu $25 \%$ dari volume reaktor terisi (400 L). Alat utama yang digunakan adalah digester anaerobik untuk proses fermentasi.

\section{Proses Pembuatan Gas Bio}

Limbah padat dan cair industri tapioka dimasukkan ke dalam tangki digester yang memiliki volume $400 \mathrm{~L}$ dengan variasi komposisi limbah padat : limbah cair adalah 70:30; 60:40; 50:50; 40:60 dan 30:70 (dalam \% massa). Kemudian ditambahkan starter (kotoran sapi) dan difermentasikan. Tangki digester dihubungkan dengan bladder (tempat penampungan gas) sehingga gas yang terbentuk akan masuk ke bladder. Volume gas diukur setiap tiga hari. Pada tahap ini, percobaan dilakukan pada digester anaerobik sistem batch dengan $\mathrm{pH}$ dijaga konstan antara 6,7 - 7,6 dengan menggunakan larutan penyangga (buffer), yaitu larutan kapur $\left(\mathrm{Ca}(\mathrm{OH})_{2}\right)$ atau kapur $\left(\mathrm{CaCO}_{3}\right)$ pada temperatur lingkungan. Bakteri anaerobik yang telah diaklimatisasi dicampur dengan limbah dengan perbandingan jumlah limbah : kotoran sapi adalah 75 : 25 (dari perancang digester), lalu diamati parameterparameter percobaan yaitu Total Suspended Solid (TSS). Periode pengamatan parameter idealnya ditentukan dengan penyesuaian terhadap waktu yang diperoleh selama tahap aklimatisasi. Tetapi dalam penelitian ini, pengamatan dilakukan setiap 3 hari.

\section{Penentuan Konsentrasi Total Suspended Solid (TSS)}

Kertas saring dipanaskan pada suhu $105^{\circ} \mathrm{C}$ selama 1 jam lalu dinginkan dalam desikator dan timbang hingga beratnya konstan (B gram). Diambil $10 \mathrm{ml}$ sampel lalu saring dan residu pada kertas saring dipanaskan pada $105^{\circ} \mathrm{C}$ selama 1 jam lalu masukkan dalam desikator dan timbang hingga berat konstan (A gram).

Kadar zat padat tersuspensi (TSS) dapat dihitung dengan persamaan 1 .

$$
\operatorname{TSS}\left(\frac{\mathrm{mg}}{\mathrm{L}}\right)=\frac{(\mathrm{A}-\mathrm{B}) \times 1000}{\mathrm{C}}
$$

Dimana:

$\mathrm{A}=$ Berat filter dan residu sesudah pemanasan $105{ }^{\circ} \mathrm{C}(\mathrm{mg})$

$\mathrm{B}=$ Berat filter kering sesudah pemanasan 105 ${ }^{\circ} \mathrm{C}(\mathrm{mg})$

$\mathrm{C}=$ Volume sampel $(\mathrm{ml})$

\section{Hasil dan Pembahasan}

Pengaruh Komposisi Bahan Baku Terhadap Persentase Penyisihan Total Suspended Solid (TSS)

Karakteristik yang diperoleh pada pembuatan gas bio dari limbah padat dan cair industri tapioka dengan pengaruh komposisi terhadap persentase penyisihan Total Suspended Solid) (TSS) dapat dilihat pada gambar 1 .

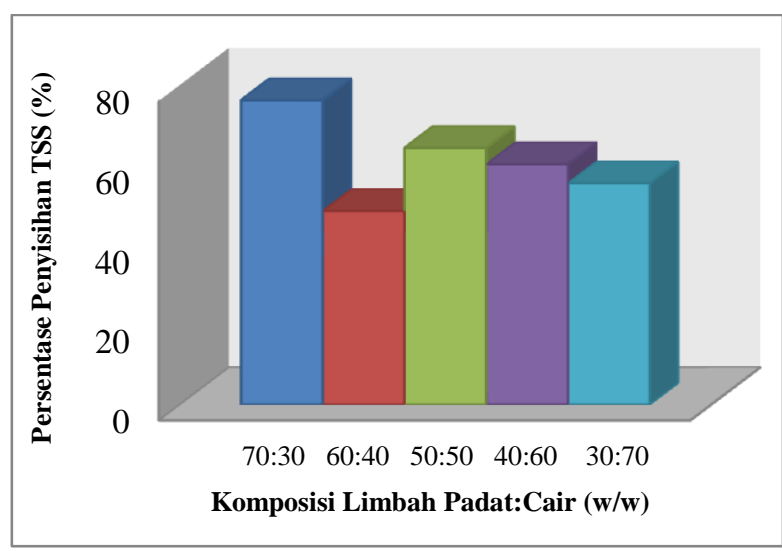

Gambar 1. Pengaruh Komposisi Terhadap Persentase Penyisihan Total Suspended Solid (TSS) 
Dari gambar 1 dapat dilihat bahwa persentase penyisihan TSS (Total Suspended Solid) cenderung berfluktuasi, namun memberikan persentase tertinggi yaitu pada perbandingan komposisi berat ampas singkong dan limbah cair 70:30 yaitu 76,2289\% dan terendah yaitu pada perbandingan komposisi berat antara ampas singkong dan limbah cair 60:40 dengan persentase 48,4928\% pada hari yang sama yaitu hari ke-33.

Pada perbandingan komposisi berat ampas singkong dan limbah cair 70:30, persentase penyisihan TSS (Total Suspended Solid) adalah $76,2289 \%$, untuk perbandingan komposisi berat ampas singkong dan limbah cair 60:40, persentase penyisihan TSS adalah $48,4928 \%$ sedangkan pada perbandingan komposisi berat ampas singkong dan limbah cair 50:50 diperoleh persentase penyisihan TSS yaitu 64,2857\%. Kemudian untuk perbandingan komposisi berat ampas singkong dan limbah cair 40:60 diperoleh persentase sebesar $60,1953 \%$, dan untuk perbandingan komposisi berat 30:70 diperoleh persentase penyisihan TSS sebesar $55,4636 \%$.

Secara teori, TSS atau total suspended solid adalah padatan total yang tertahan oleh saringan dengan ukuran partikel maksimal $2 \mu \mathrm{m}$ atau lebih besar dari ukuran partikel koloid. Yang termasuk TSS adalah lumpur, tanah liat, logam oksida, sulfida, ganggang, bakteri dan jamur. TSS umumnya dihilangkan dengan flokulasi dan penyaringan. TSS memberikan kontribusi untuk kekeruhan (turbidity) dengan membatasi penetrasi cahaya untuk fotosintesis dan visibilitas di perairan, sehingga nilai kekeruhan tidak dapat dikonversi ke nilai TSS [8].

Dari hasil analisis yang dilakukan oleh Widayatno dan Sriyani (2008) terhadap sampel limbah industri tapioka didapatkan kadar Total Suspended Solid (TSS) sebelum pengolahan adalah $1160 \mathrm{mg} / \mathrm{L}$, sedangkan hasil campuran antara ampas singkong dan limbah cair memberikan nilai TSS yang cukup tinggi pada berbagai perbandingan.

TSS yang relatif tinggi dalam aliran umpan akan membutuhkan waktu tinggal cairan lebih lama dalam reaktor agar dapat terlarut (terhidrolisis) dan terurai oleh mikroorganisme anaerob menjadi senyawa-senyawa lebih sederhana. Penggunaan waktu tinggal cairan 12-24 jam belum cukup memadai untuk berlangsungnya proses hidrolisis dan degradasi biologis kandungan padatan tersuspensi dalam aliran umpan limbah cair [5].

Dalam hal ini, pada proses batch dimana umpan sekaligus dimasukkan maka mikro organisme memiliki waktu yang cukup untuk mendegradasi kandungan padatan yang ada di dalam limbah sehingga bila kandungan padatan semakin tinggi maka efisiensi penyisihan juga akan semakin besar [2].

Berdasarkan Keputusan Menteri, batas maksimum TSS adalah $60 \mathrm{mg} / \mathrm{L}$ [15] dan hasil pengolahan campuran ampas singkong dan limbah cair menjadi gas bio memberikan hasil akhir TSS paling sedikit adalah $1238 \mathrm{mg} / \mathrm{L}$ yaitu pada perbandingan berat ampas singkong dan limbah cair 70:30, tetapi penyisihan TSS paling kecil yaitu pada perbandingan berat ampas singkong dan limbah cair 60:40.

Jadi, dengan nilai TSS yang tinggi tidak memungkinkan untuk dibuang ke lingkungan, sehingga perlu dimanfaatkan hasil samping gas bio yaitu sebagai pupuk cair [14] dan alternatif lain seperti yang dilakukan Siallagan (2010) dengan menambahkan koagulan yaitu biji asam jawa sehingga persentase penyisihan TSS akan semakin besar dan memenuhi baku mutu limbah dengan nilai TSS limbah cair olahan $26 \mathrm{mg} / \mathrm{L}$ tercapai pada kondisi perbandingan limbah cair industri tahu (dengan proses koagulasi) dan air 1:0,25 dimana sebelum proses koagulasi nilai TSS sebesar $42 \mathrm{mg} / \mathrm{L}$.

Berdasarkan gambar 1., semakin besar jumlah limbah padat maka semakin besar penyisihan TSS walaupun hal ini tidak berlaku untuk perbandingan 60:40. Adapun hal ini kemungkinan disebabkan adanya produk tengah (intermediate) yang dapat membatasi proses degradasi seperti proses degradasi lemak menghasilkan asam lemak yang dapat menghambat proses degradasi selanjutnya, adanya inhibisi pada metanogenesis karena peningkatan dari inhibitor tidak terhidrolisis seperti sulfida dan inhibisi dalam reaksi karena adanya peningkatan dari amonia bebas [1].

\section{Kesimpulan}

Pengaruh antara komposisi bahan baku terhadap persentase penyisihan Total Suspended Solid (TSS) adalah semakin besar kandungan ampas singkong (limbah padat) maka persentase penyisihan akan semakin besar walaupun hal ini tidak berlaku pada perbandingan 60:40. Dalam hal ini, persentase penyisihan Total Suspended Solid (TSS) terbesar yaitu pada perbandingan berat ampas padat dan limbah cair 70:30 dengan nilai $76,2289 \%$.

\section{Daftar Pustaka}

[1] Deublein, Dieter and Steinhauser, Angelika. "Biogas From Waste and Renewable Resources. An Introduction.” (Wiley-VCH Verlag GmbH \& Co.: Weinhem, 2008), hal 49-65.

[2] Febyanti, Agnita, Adrianto Ahmad, dan Bahruddin., Pengaruh Laju Alir Umpan Terhadap Penyisihan Kandungan Padatan 
Limbah Cair Industri Minyak Sawit Dengan Bioreaktor Hibrid Bermedia Batu Skala Pilot Plant, Seminar Nasional Fakultas Teknik-UR, 29-30 Juni 2010, hal 1-10

[3] Ferrer, Ivet; Sergio Ponsa; Felicitas Vasquez dan Xavier Font, Increasing Biogas Production by Thermal $\left(70^{\circ} \mathrm{C}\right)$ Sludge PreTreatment Prior to Thermophilic Anaerobic Digestion, Biochemical Engineering Journal 42 (2008) 186-192.

[4] Harahap, Indri Vesalina, Uji Beda Komposisi Campuran Kotoran Sapi Dengan Berbagai Jenis Limbah Pertanian Terhadap Biogas Yang Dihasilkan, repository.usu.ac.id, 2009, diakses tanggal 25 April 2012.

[5] Husin, A, Pengolahan Limbah Cair Industri Tahu Dengan Biofiltrasi Anaerob Dalam Reaktor Fixed - Bed, Tesis, Universitas Sumatera Utara, Medan dalam Siallagan, Nurmay Siska Rosilawati, 2010, Pengaruh Waktu Tinggal dan Komposisi Bahan Baku Pada Proses Fermentasi Limbah Cair Tahu Terhadap Produksi Biogas, Departemen Teknik Kimia USU: Medan, 2008.

[6] Kapdi, Shyam S.; Vijay, Virendra K.; Rajesh, Shivanalli K.; dan Prasad, Rajendra, Upgrading Biogas For Utilization as a Vehicle Fuel, Asian Journal on Energy and Environment, As. J. Energy Env, 2006, 7(04), 387-393.

[7] Krober, Magdalena; Bekel, Thomas; Diaz, Naryttza N.; Goesmann, Alexander, Jaenicke, Sebastian; Krause, Lutz; Dimitri Millera, Kai J. Runte, Prisca Viehoverc, Alfred Puhler, Andreas Schluter, Phylogenetic Characterization of a Biogas Plant Microbial Community Integrating Clone Library 16SrDNA Sequences and Metagenome Sequence Data Obtained by 454-pyrosequencing, Journal of Biotechnology 142 (2009) 38-49.

[8] Novie, Total Suspended Solid (TSS), http://environmentalchemistry.wordpress.co m/, Diakses pada tanggal 7 Maret 2013, 2012.
[9] Panichnumsin, Pornpan dan Nopharatana, Annop, Anaerobic Co-Digestion of Cassava Pulp and Pig Manure : Effects of Waste Ratio and Inoculum-Substrate Ratio, JGSEE, 2008.

[10] Siallagan, Nurmay Siska Rosilawati, Pengaruh Waktu Tinggal dan Komposisi Bahan Baku Pada Proses Fermentasi Limbah Cair Tahu Terhadap Produksi Biogas, Tesis. USU: Medan, 2010.

[11] Surya, Optimasi Produksi Biogas Pengolahan Limbah Cair Industri Tapioka Sebagai Sumber Energi Alternatif Terbarukan. http://permimalang.wordpress.com/, Diakses pada tanggal 29 April 2012, 2009.

[12] Tarigan, Ramli, Pemanfaatan Biogas Kotoran Ternak Sapi Sebagai Pengganti Bahan Bakar Minyak Dan Gas. http://www.repository.usu.ac.id, Diakses pada tanggal 3 Agustus 2012, 2008.

[13] Ubalua, A.O, Cassava Wastes: Treatment Options and Value Addition Alternatives, African Journal of Biothechnology. Vol 6 (18), pp. 2065-2053, 19 September 2007.

[14] Wahyuni, Sri, Biogas Energi Terbarukan Ramah Lingkungan dan Berkelanjutan, Kipnas: Jakarta, 2011.

[15] Widayatno, Tri dan Sriyani, Pengolahan Limbah Cair Industri Tapioka Dengan Menggunakan Metode Elektroforesis, Prosiding Seminar Nasional Teknoin dalam Bidang Teknik Kimia dan Tekstil, Yogyakarta, 22 November 2008.

[16] Widowati dan Dianawati, Pemanfaatan Limbah Cair Tepung Tapioka Sebagai Bahan Baku Nata de Cassava, Buana Sains. Volume 9. Nomor 1- Juni 2009.

[17] Zahro, L Mu'nisatus, Laporan Final. http://eprints.undip.ac.id/, Diakses pada tanggal 25 April 2012, 2010. 